\title{
Sociotherapy took me out of my solitude
}

\section{Mutegwamaso Foyibi}

I am fifty-eight years old. I have been a widow since 1995. Because of the ethnic conflicts that reigned in Rwanda over a period of many years, I grew up and lived in different neighbouring countries. I returned to Rwanda in 1992, at the age of thirty-eight. I was born into a family of six children, four of whom died during the genocide. Only one sister and I are still alive. I married my husband in 1968 when I was fourteen years old. We had seven children together. Four are alive, the three others died during the genocide.

In the 1963 war, when I was nine years old, our family fled to Burundi. This war followed previous wars that took place in 1959 and in 1962 . We fled this time because our house was destroyed and most of the members of my extended family were murdered. In 1974, my parents and some siblings went back to Rwanda because the country was peaceful. My husband did not want us to go back with them. Instead, we took refuge in Uganda.

Life in Uganda was very bad for me. First of all, my mother-in-law was wicked to me. She used to beat me and her other daughters-in-law. I was still very young, unable to take decisions. I disliked Uganda because I suffered a lot. I looked after the cows, even during heavy rains or under strong sun. I did not feel happy. In contrast, I had had a good life as a child. I had lived with my family in a nice house and a peaceful environment. I did not want to stay in Uganda, but I could not leave my children. I had a tense, stressful life until I came back to Rwanda with my children in 1992.
Just after we had returned, the 1992 genocide happened. Perpetrators burned our houses. We ran off to the Nyamata Catholic Church and a week later went back to our ruined houses. I expected mass killings to happen, but could not picture it in my mind. I did expect it, for instance, when soldiers came to our house and started messing up our stored sorghum and beans, saying that they were searching for guns. Subsequently, they took us to the banana plantation and hit us. While beating us, they were telling us that they would kill us before we would be able to reach the church. They were also saying that those who hid in the church would be killed inside. We thought these were lies. As in previous wars, we thought, no one would slaughter people in a church. Then, after almost two years, the 1994 genocide happened.

In this year, after the crash of president Habyarimana's plane, the Interahamwe killed two men in Nyamata. We fled in fear to the high mountain of Kayumba. We could not go back to our home, where I was born, because the situation there was terrifying. We thought the violence would only last a few days. Three days turned out to be three months.

After we arrived at Kayumba, Hutus and soldiers from the Gako military camp spent the whole night shooting people with their guns. I was with my brother, my sister-in-law and one of my children. The other children were with their grandparents. When the shooting continued, we ran away to search for a place to hide. We arrived at the house of an Interahamwe who was our friend. 
Unfortunately, he told us that he could not do anything for us because of the horrifying situation outside.

Because we had nowhere else to go, we went to the Catholic Church of Nyamata. After killing and 'finishing off', as the Interahamwe called it, most of those inside the church, the survivors left the church, including my son and me. Arriving at Rwakibirizi, we were stopped at a roadblock. There I was separated from my son and the others who were with us. They all died. This saddened me. From the roadblock I ran away towards the nearby swamp. The killers found me there and brought me to their homes. There, they spent many hours discussing what to do about me. Some were asking me whether or not I was Tutsi. I said I was Hutu so that they would let me leave.

They were not convinced, so they took me to the house of a lady who was a specialist in killing children. ${ }^{a}$ She used to kill women and smash children. ${ }^{\mathrm{b}}$ They told this woman to take me to the house of the conseiller ${ }^{c}$ in her neighbourhood. I was afraid, because everybody who was taken to the conseiller's house was killed. On our way to that house, we met a crowd of Interahamwe who were going to the church to beat the dead bodies that were inside. I was naked, because the Interahamwe had taken my clothes when I was inside the church. I only had a black scarf over my head, because I wanted to hide my face. The Interahamwe

\footnotetext{
a This lady was the only woman to kill Tutsi children in her neighbourhood during the genocide. Mutegwamaso calls her a specialist because it is uncommon for a woman to kill children.

b To 'smash children' means to crush or grind children to death using a mortar; a traditional tool used mostly to crush cassava, especially in rural areas.

c A conseiller (advisor in English) was at the time an elected representative of a sector, which is an administrative entity smaller than a district or municipality.
}

we met on the street did not do anything to us. They thought that we were also Hutus because we were walking around freely and not in hiding, as the Interahamwe presumed all Tutsis were doing. After outrunning the crowd, the woman who had been told to take me to the conseiller's house left me, saying that I should go further on my own because there was no killer around.

I sought refuge with the family of a Hutu man and a Tutsi woman, who was my cousin. However, she chased me away, saying that she could not do anything for me. I had not expected that, instead thinking that if I would hide there nobody would kill me since her husband was Interahamwe. She was evil. She also chased her own father and mother away, after which perpetrators killed them both.

Instead of going away, I insisted until she showed me an old house nearby. Her husband later learned that I was in that house. Since he was a friend of my brothers, he made his house helpers come to take me to his home and place me in a small house behind his main house. Arriving later in front of my cousin's husband, I begged him to shoot me. He said that he would not kill me. He told his house helpers that I was his sister. He sent me back to the small house behind the main house.

After a few days, a woman and a young girl joined me there. At one point, I heard my cousin discussing with the Interahamwe, saying that they should rape us. There were many of them. Sadly, I did not recognize them, which means that I could not denounce them later. They knew me, however, because I was an evangelist in the Anglican Church. I only met one rapist in Gacaca, when he apologized for having raped me.

After the genocide, I joined other older women in Nyamata town. During this time, I was like a mad person. Walking naked in 
open places was not a problem for me. While people were returning to their previous homes, I lived with young children who were orphans from all over. After joining them, I fell sick. I could not move. I suffered from a severe sexually transmitted infection until the children took me in a wheelbarrow to the hospital. There I had a miscarriage after a long illness. I must have been impregnated by one of the rapists.

During the whole period following the genocide, I suffered from amoeba due to the drinking of uncooked rainwater, back pain and grief. Whenever I thought about the rape, I felt headaches. I fell sick every year, especially during the commemoration period. When someone is showing ihahamuka I understand him or her. Each time I thought of my lost relatives or what had happened to me, I felt fire in my head and my ears became deaf. I felt hate for everybody around me and I hated myself as well. Immediately after the genocide I was treated, but the infection I got has not been cured; I still have sores on my private parts. I got medical care after I received mutual health insurance from FARG, but back and hip pain remain. I think that my state of health is not improving because I am always wondering when I will get my own house.

Because I was known to be a traumatized woman, in 2008 I was invited by Ibuka, to be trained as a lay trauma counsellor. This training helped me. I would not have survived without it. The symptoms of suffering that were listed during the training were all symptoms I was suffering from. I was ashamed. I was always thinking that everybody hates me. After the training I felt my heart releasing; not completely, but at least a bit.

I received trainings from different institutions. While Ibuka and AVEGA trained us about trauma counselling and how to accompany traumatized people during the Gacaca court processes, Kanyarwanda trained us about trauma, ihahamuka, HIV and reproductive health. World Vision trained us about personal development, and in particular about the process of individual bereavement. REACH trained me about reconciliation and forgiveness. I became a local trainer for REACH in Nyamata. Together with some other local trainers we facilitate the process of apology and forgiveness that should lead to reconciliation.

An after effect of the genocide was being re-traumatized by Gacaca. The rapist who confessed to raping me bribed the judges. $\mathrm{He}$ had wanted to do the same with me. As a kind of apology he brought me some money, begging me to not testify against him again in Gacaca. I told him: "The money you brought to me cannot cleanse the sin you committed against my humanness. I will continue to denounce you until the end of Gacaca. Money cannot heal the sadness you injected in me. That money is not a deodorant which may remove the bad smell you had, because up to now, I still feel your bad smell. If you would come without money, I could forgive you." He gave the amount of money meant for me to the Gacaca judges. The result is that they set him free and helped him to flee. I was betrayed by the court when they released the man who raped me after he had confessed. I felt unhappy because the Gacaca judges did not consider my testimony. I was wounded by this event and decided never to attend Gacaca again.

In 2011, I joined sociotherapy. A woman I had befriended during Ibuka's training convinced me to join. She tried to explain how sociotherapy works to me. I told her that my problems are known everywhere, which is more than enough for me: "I do not want to continue spreading them." My friend 
insisted, and finally I went with her to attend sociotherapy sessions. In the group I met other women who have been abused like me. We started discussing and I appreciated our discussions. Since then, I decided to participate in each weekly session.

Before I joined sociotherapy, I had shared my story with three people. One was a nurse, to whom I had to tell my suffering in order to get treatment for the sexually transmitted infections that resulted from the rape. After talking about this experience for the first time, I had felt guilt, because I had decided to keep this rape in my heart in order to avoid my children knowing about it.

After joining other women in sociotherapy, I developed trust in the group members because we had the same problems. When I tried to compare my problems to those of others, I realised that mine were insignificant. For example, there are some who got infected with HIV, which I did not get. I also learned that I was not the only one who had been raped. Before speaking, I was already happy to be part of such a group because we had the same problem. When I shared my story, I felt released and I stepped out of my suffering. Since then, I have not been afraid to talk about the rape anymore. Before joining sociotherapy I had symptoms of trauma and ihahamuka. During sociotherapy sessions, my anger has reduced and the depression has gone. I gained hope and security in my heart.

At the beginning of sociotherapy, I was expecting to receive constructive advice, as my friend had promised I would. What I liked was how we shared our bad experiences and exchanged advice. We were open. We talked about everything. This healed my heart. All of the trainings I benefitted from helped me to learn more about all of the symptoms I was feeling in my body. But only sociotherapy helped me to feel free and helped me talk in the group about the unspeakable rape I had endured. I hope that we will continue to meet.

Regarding my relationship with others, sociotherapy has helped me become patient. Instead of living in loneliness, I chat with others. Sociotherapy took me out my solitude. It helped me improve communication with my children as well, since before I was always insulting them. Finally, I gained a feeling of safety and trust. However, while sociotherapy healed my genocide-related wounds, I am worried about covering the school fees for my children who live with me - two children of my brother who was killed during the genocide and one grandchild.

As someone healed by sociotherapy, I would advise all women who live with problems to cooperate with others and talk with them about their problems. Before, I had lost my senses. After joining sociotherapy, I felt that I was a human being again. It helped me to know that I was not the only one who thought that I was not a human being anymore. I used to be known as a mad person, but now the ihahamuka I used to experience has disappeared.

Speaking is a process of healing. When you meet other people and talk with them, like we did in the sociotherapy group, you learn from each other and advise each other on how to deal with problems. This advice helps you gain strength. In addition, when people listen to you, you do not feel lonely anymore. 